\title{
Serological markers in progressive systemic sclerosis: clinical correlations
}

\author{
L. J.CATOGGIO, ${ }^{1}$ R. M.BERNSTEIN $,{ }^{2} \mathrm{C} \cdot \mathrm{M} \cdot \mathrm{BLACK},{ }^{2} \mathrm{G} \cdot \mathrm{R} \cdot \mathrm{V} \cdot \mathrm{HUGHES},{ }^{2}$ \\ AND P. J. MADDISON ${ }^{1}$ \\ From the ${ }^{1}$ Royal National Hospital for Rheumatic Diseases, Upper Borough Walls, Bath BA1 1RL, and the \\ ${ }^{2}$ Rheumatology Unit, Department of Medicine, Hammersmith Hospital, Du Cane Road, London W12
}

SUMMARY The relation between clinical and serological findings was studied in 75 patients with definite progressive systemic sclerosis (PSS). Antinuclear antibodies were detected by indirect immunofluorescence in $95 \%$ of the patients by means of HEp- 2 cells. The centromere pattern was observed in $50 \%$ of the patients with calcinosis, Raynaud's phenomenon, oesophageal dysmotility, sclerodactyly, and telangiectasia (CREST) and only $7 \%$ of the group with diffuse disease. Precipitating antibodies to nuclear and cytoplasmic antigens were detected by immunodiffusion in $53 \%$ of the patients and identified as anti Scl-70 in $16(21 \%)$. We confirmed that autoantibodies are very frequent in PSS but varied in specificity. A combination of immunodiffusion and indirect immunofluorescence was useful in detecting antibodies characteristic of PSS (i.e., anti-Scl-70 and anticentromere) in $51 \%$ of these patients. Anticentromere antibody has a high specificity for CREST and identifies patients with less severe disease (i.e., more prolonged course and less involvement of internal organs). Anti-Scl-70 was associated with a high frequency of lung involvement.

Progressive systemic sclerosis (PSS) is a chronic disease of unknown aetiology affecting connective tissue and small arteries. Its outcome is unpredictable because life-threatening systemic involvement may become apparent only late in the course of disease. ${ }^{1-3}$

The presence of autoantibodies is now recognised to be a prominent feature of PSS. Serological abnormalities reported to be characteristic of this disease include precipitating antibodies to the uracyl bases in single-stranded RNA, ${ }^{45}$ precipitating antibodies to a soluble 70000 Dalton nuclear protein called Scl-70, ${ }^{6}$ antinucleolar antibodies, ${ }^{7}$ and antibodies directed to the centromere region of chromosomes. ${ }^{8}$ Recently anticentromere antibody (ACA) has been reported to characterise the CREST variant of PSS. ${ }^{9}{ }^{10}$ Such autoantibodies may be of great value if they lead to the earlier diagnosis of PSS or the identification of subsets with differing prognosis.

In the present study we have investigated the frequencies and clinical associations of these and other autoantibodies in the sera of 75 patients with PSS.

Accepted for publication 15 January 1982.

Correspondence to P. J. Maddison, MD, MRCP, Royal National Hospital for Rheumatic Diseases, Upper Borough Walls, Bath BA1 1 RL.

\section{Patients and methods}

Seventy-five patients with definite PSS $^{3}$ were evaluated by at least one of the authors using the same clinical protocol at the Royal National Hospital for Rheumatic Diseases, Bath, and the Hammersmith Hospital, London. The protocol included full history and physical examination, radiographs of chest and hands, barium swallow examination, lung function tests including carbon monoxide transfer (TLCO), electrocardiogram, Schirmer's test of tear secretion, estimations of serum creatine phosphokinase, creatinine clearance and 24-hour urine protein excretion, and examination of the urine sediment.

Internal organ involvement was defined as follows. Oesophageal: abnormal motility determined radiologically. Pulmonary: bibasilar fibrosis on chest radiograph or a TLCo of less than $75 \%$ of the predicted value. Renal: creatinine clearance $<60$ $\mathrm{ml} / \mathrm{min}$, active sediment, proteinuria exceeding 0.5 $\mathrm{g} /$ day, or accelerated hypertension, in the absence of other cause. Myositis: weakness plus elevated creatine phosphokinase (CPK), abnormal electromyogram (EMG), or characteristic biopsy appearance. Cardiac: clinical or electrocardiographic 
(ECG) abnormalities in the absence of other cause. Arthritis: soft tissue swelling observed by a physician. Small and large bowel involvement was not assessed radiologically in all cases and was excluded from the study.

Serum from 100 patients with other connective tissue diseases was studied to determine the frequency of anti-Scl-70 and ACA.

Serum was stored at $-20^{\circ} \mathrm{C}$ and examined without knowledge of the clinical data.

Immunofluorescence. The substrate for indirect immunofluorescence (IMF) was a cell line, HEp-2, originally derived from a human laryngeal carcinoma. Sera diluted 1:40 in phosphate-buffered saline (PBS) $(0.14 \mathrm{M} \mathrm{NaCl}, 0.01 \mathrm{M}$ phosphate, $\mathrm{pH}$ $7 \cdot 4$ ) were incubated for 30 minutes at room temperature on HEp-2 cells adherent to glass slides (Antibodies Incorporated, Davis, California, USA). The slides were washed in PBS for 10 minutes and then incubated with a fluorescein-conjugated goat antihuman $\operatorname{lgG}$. After a further wash in PBS for 10 minutes the slides were mounted in glycerol 1:1 in PBS and examined at 500 times magnification.

Immunodiffusion. Precipitating antibodies to soluble nuclear and cytoplasmic antigens were detected by the Ouchterlony technique using fresh extracts of rabbit thymus powder (Pel-Freez, Arkansas, USA) as the source of Scl-70, human spleen extract for Ro (SSA), and extracts of calf thymus and calf thymus nuclei for Sm, nRNP, La (SSB), and PM-Scl-DM..$^{9-14}$ Since the Scl-70 antigen is very labile, rabbit thymus extract was used freshly made: $1.2 \mathrm{~g}$ of powder was dissolved in $20 \mathrm{ml}$ of PBS pH $7 \cdot 2$ and stirred at $4^{\circ} \mathrm{C}$ for 4 hours. After centrifugation at $3000 \mathrm{rpm}$ at $4^{\circ} \mathrm{C}$ for 30 minutes the supernatant was concentrated to approximately $40 \mathrm{mg}$ of protein per $\mathrm{ml}$.

In 32 patients counterimmunoelectrophoresis (CIE) was used to identify precipitating antibodies to calf liver ssRNA, polyuridylic acid (poly-U), and polyadenylic-polyuridylic acid (poly-A-poly-U) by previously described methods. ${ }^{4515}$ The antigens were obtained from Sigma Chemicals and used at a concentration of $25 \mu \mathrm{g} / \mathrm{ml}$.

Statistical significance was assessed by the chisquared test.

\section{Results}

Clinical findings of the 75 patients with PSS are shown in Table 1. Sixty-six were female. Twenty-nine patients had diffuse skin involvement and 32 patients had the CREST variant ( 4 or 5 of the features: calcinosis, Raynaud's phenomenon, oesophageal dysmotility, sclerodactyly or acrosclerosis without diffuse scleroderma, and telangiectasia). The remaining 14 patients had at least 3 of these features and were termed 'incomplete CREST.' Systemic involvement was greater in patients with diffuse scleroderma and the median duration of disease was shorter (Fig. 1). Furthermore 3 of these 29 patients died during a 2-year period of observation. Patients with CREST syndrome were of similar mean age but with a longer disease duration, less internal organ involvement,

Table 1 Systemic involvement in PSS subgroups

\begin{tabular}{|c|c|c|c|}
\hline & Diffuse & CREST & $\begin{array}{l}\text { Incomplete } \\
\text { CREST }\end{array}$ \\
\hline Number of patients & 29 & 32 & 14 \\
\hline $\begin{array}{l}\text { Age (years: mean and } \\
\text { range) }\end{array}$ & $53(29-69)$ & $56(31-73)$ & $46(27-67)$ \\
\hline $\begin{array}{l}\text { Disease duration (years: } \\
\text { median and range) }\end{array}$ & $6(1-43)$ & $15(2-37)$ & $9(2-20)$ \\
\hline Calcinosis (\%) & 59 & 78 & 21 \\
\hline Raynaud's (\%) & 93 & 100 & 100 \\
\hline Telangiectasia $(\%)$ & 83 & 97 & 43 \\
\hline Arthritis (\%) & 48 & $22(p<0.05)$ & 14 \\
\hline Myositis (\%) & 24 & 6 & - \\
\hline Oesophageal ( $\%$ ) & 72 & 81 & 36 \\
\hline Pulmonary $(\%)$ & 62 & 41 & 28 \\
\hline Renal (\%) & 24 & 12 & 7 \\
\hline Cardiac (\%) & 24 & 12 & - \\
\hline Sjögren's (\%) & 10 & 16 & - \\
\hline
\end{tabular}

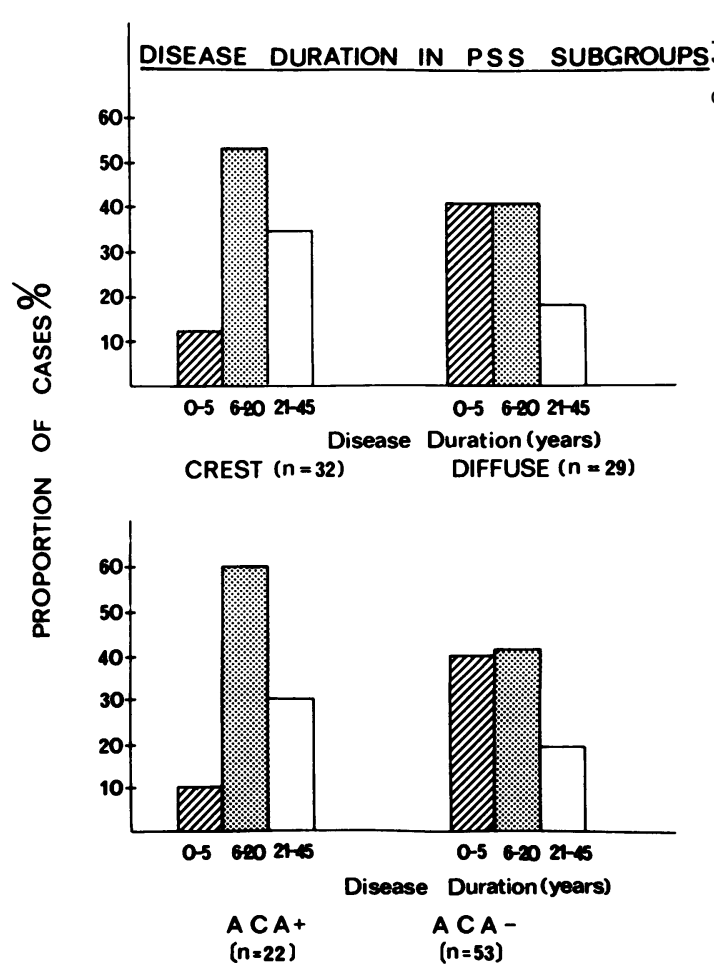

Fig. 1 Disease duration in the different PSS subgroups. Note the similarity in distribution between the CREST and $A C A$-positive groups and the diffuse and $A C A$-negative groups. 
and no recent mortality, confirming an earlier onset and more benign course in the CREST variant of PSS. Patients with incomplete CREST had a somewhat shorter duration of disease, less calcinosis and telangiectasia, and less internal organ involvement, suggesting earlier and/or milder disease.

Antinuclear antibodies. Using HEp-2 cells as the substrate for immunofluorescence, we detected ANA in 71 of 75 sera (95\%). Several patterns were seen as previously described ${ }^{16}$ : centromere, diffusely grainy, homogeneous, fine speckles, and coarse speckles. A variety of nucleolar staining patterns was combined with nuclear staining in $36 \%$ of cases. The centromere pattern was observed in 22 patients

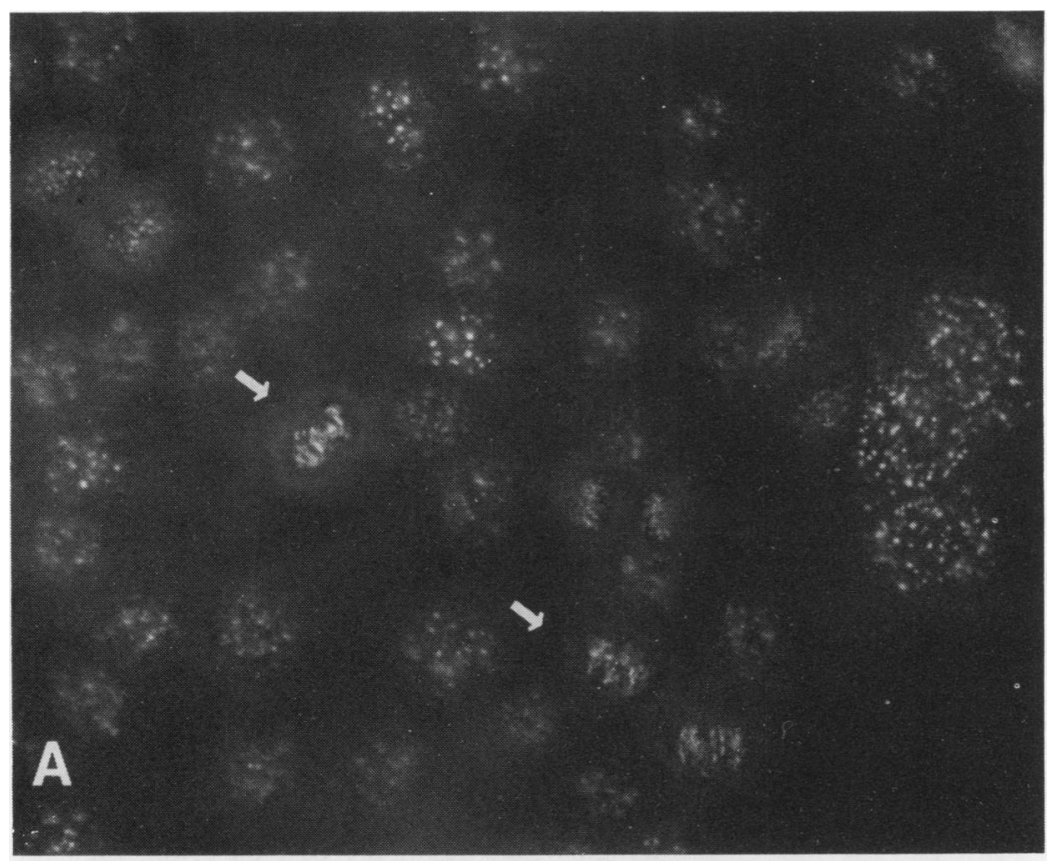

Fig. 2 Indirect immuno-

fluorescence with HEp-2 cells. Centromere pattern: discrete coarse speckles in interphase nuclei are seen to cluster at the metaphase plate of dividing cells $(A$, arrows) and later accompany daughter cells in anaphase and telophase ( $B$, arrows). These speckles have been shown to correspond to the centromere of chromosomes. $(\times 500)$. 
$(29 \%)$ as discrete large speckles in interphase nuclei with characteristic clustering during mitosis (Fig. 2).

Precipitating antibodies to extractable antigens. Precipitating antibodies were detected in 40 of the 75 sera $(53 \%)$. They included anti-Scl-70 in 16 sera (21\%) and anti-nRNP, anti-Ro, and anti-PM-Scl$\mathrm{DM}^{14}$ in 3 sera each. The remaining 15 precipitins, detected chiefly with calf thymus nuclear extract, were not identical to other known precipitin systems and were heterogeneous among themselves.

Antibodies to ssRNA. Only 4 of 32 sera had antibodies to single-stranded RNA. In contrast to previous reports ${ }^{4}$ these antibodies reacted with doublestranded poly-A-poly-U and failed to react with poly-U.

Clinical associations. Table 2 shows the frequencies of anticentromere and anti-Scl-70 antibodies in PSS compared with other connective tissue diseases. Anticentromere antibodies occurred in the sera of $50 \%$ of patients with definite CREST, $28 \%$ with incomplete CREST, $7 \%$ with diffuse PSS, $7 \%$ with primary Raynaud's phenomenon, and $2 \%$ with SLE. Anti-Scl-70 occurred in $21 \%$ of PSS sera and in only one other case, a patient with polymyositis.

Table 2 Frequency of anti-Scl-70 and ACA in various connective tissue diseases

\begin{tabular}{llll}
\hline & $\begin{array}{l}\text { Number of } \\
\text { patients }\end{array}$ & ACA & Anti-Scl-70 \\
\hline PSS total & 75 & $22(29 \%)$ & $16(21 \%)$ \\
$\quad$ diffuse & 29 & $2(7 \%)$ & $10(34 \%)$ \\
CREST (definite) & 32 & $16(50 \%)$ & $4(12 \%)$ \\
CREST (incomplete) & 14 & $4(28 \%)$ & $2(14 \%)$ \\
Primary Raynaud's & 15 & $1(7 \%)$ & 0 \\
SLE $^{18}$ & 50 & $1(2 \%)$ & 0 \\
Polymyositis $_{\text {Rheumatoid arthritis }}^{19}$ & 10 & 0 & $1(10 \%)$ \\
Overlap syndromes $^{18}$ & 10 & 0 & 0 \\
\hline
\end{tabular}

$\mathrm{ACA}=$ Anticentromere antibodies

Table 3 Clinical associations of ACA and anti-Scl-70

\begin{tabular}{|c|c|c|c|c|}
\hline & \multicolumn{2}{|l|}{$A C A$} & \multicolumn{2}{|l|}{ Anti-Scl-70 } \\
\hline & + & - & + & - \\
\hline $\begin{array}{l}\text { Number of patients } \\
\text { Age (years: mean }\end{array}$ & 22 & 53 & 16 & 59 \\
\hline $\begin{array}{l}\text { and range) } \\
\text { Disease duration } \\
\text { (years median }\end{array}$ & $56(34-73)$ & $50(27-73)$ & $50(27-68)$ & $51(29-73)$ \\
\hline $\begin{array}{l}\text { (years: median } \\
\text { and range) } \\
\text { Diffuse skin }\end{array}$ & $17(1-37)$ & $8 \cdot 5(1-43)$ & $9(2-43)$ & $11(1-37)$ \\
\hline involvement (\%) & 9 & $51(p<0.02)$ & 62 & 32 \\
\hline CREST (\%) & 73 & $28(\mathrm{p}<0.01)$ & 25 & 47 \\
\hline Arthritis (\%) & 14 & $37(\mathrm{p}<0.05)$ & 50 & 25 \\
\hline Myositis (\%) & 3 & 15 & 31 & 5 \\
\hline Oesophageal (\%) & 69 & 67 & 75 & 66 \\
\hline Pulmonary (\%) & 34 & $54(\mathrm{p}<0.05)$ & 75 & $39(p<0.05)$ \\
\hline Renal (\%) & 9 & 20 & 19 & 17 \\
\hline Cardiac (\%) & 11 & 19 & 31 & 12 \\
\hline Sjögren's (\%) & 16 & 12 & 19 & 7 \\
\hline
\end{tabular}

$\mathrm{ACA}=$ Anticentromere antibodies.
Table 3 shows the clinical features of PSS in the presence or absence of these antibodies. Anticentromere antibody was associated with a longer duration of disease, a significant absence of diffuse skin involvement, and significantly less arthritis and pulmonary disease. Anti-Scl-70 on the other hand was associated with a significant increase in pulmonary involvement.

With regard to previously reported associations, no patient with anti-Ro had Sjögren's syndrome. ${ }^{17}$ Patients with antibody to nRNP had typical scleroderma, diffuse in 2 cases, without evidence of an overlap syndrome. None of the patients with anti-PM-Scl-DM had clinical evidence of myositis. ${ }^{14}$

\section{Discussion}

In this series of 75 patients with PSS $51 \%$ of the sera contained either anti-Scl-70 or anticentromere antibodies. These antibodies appear to have a high specificity for systemic sclerosis (over $97 \%$ in our experience), and their detection by a combination of immunodiffusion and IMF should prove helpful in the diagnosis of PSS.

Several other precipitating antibodies were found in $33 \%$ of the sera, but each occurred infrequently. Antibody specific for ssRNA was not found in thiso series. A variety of ANA patterns were detected by IMF in $95 \%$ of sera, but the only clinical associations were with anticentromere and anti-Scl- 70 antibodies.

Anticentromere antibody (ACA) was confirmed to be highly specific for the CREST syndrome. The frequency of ACA in definite CREST was $50 \%$, compared with frequencies of 55-96\% reported previously..$^{91016}$ This variability may reflect differences in patient selection. In the present series ACA was associated with longer duration of disease, absence of diffuse scleroderma, and less systemic involvement. ACA therefore distinguishes a more benign subset of PSS, previously defined purely clinically. On the other hand, when isolated Raynaud's syndrome is being considered, ACA has been detected in the serum of patients who subsequently developed CREST.$^{10}$ In either situation ACA should prove helpful in prognosis.

Antibody to Scl-70 occurred in $21 \%$ of sera and appeared to be associated with pulmonary involvement (relative risk $4 \cdot 7$ ). Sera containing this antibody gave diffusely grainy staining on IMF. However, this pattern was also seen in the absence of antibody to Scl-70, suggesting caution in linking precipitins with particular staining patterns. Similarly, while the centromere pattern is distinct, further characterisation of the antigen is required to show whether it is due to a single immunological system. Nevertheless, the remarkable clinical association of ACA with limited 
scleroderma, extending also to patients with sclerodactyly and primary biliary cirrhosis, ${ }^{20}$ and the strong HLA association of ACA with DR1 and DR5 ${ }^{21}$ both support the view that ACA is the expression of a specific immune response. Further investigation may reveal a pathogenetic role for these antibodies, and prospective studies are required to confirm the prognostic value of anticentromere antibody.

We thank Drs B. M. Ansell, P. A. Bacon, P. A. Dieppe, A. St. J. Dixon, S. P. Liyanage, B. E. W. Mace, and C. Seldman for referral of patients under their care.

L. G. Catoggio is the recipient of a scholarship from the University of Buenos Aires, Argentina.

\section{References}

1 Rodnan G P. Progressive systemic sclerosis (scleroderma). In: McCarty D J, ed. Arthritis and Allied Conditions. 9th ed. Philadelphia: Lea and Febiger, 1979: 762-809.

2 LeRoy E C. Systemic sclerosis (scleroderma). In: Kelley W R, Harris E D, Ruddy S, Sledge C, eds. Textbook of Rheumatology. Philadelphia: Saunders, 1980: 1211-27.

3 Subcommittee for Scleroderma Criteria of the Americal Rheumatism Association Diagnostic and Therapeutic Criteria Committee. Preliminary criteria for the classification of systemic sclerosis (scleroderma). Arthritis Rheuma 1980; 23: 581-90.

4 Alarcon-Segovia D, Fishbein E, Garcia-Ortigoza E, EstradaParra S. Uracil specific anti RNA antibodies in scleroderma. Lancet 1975 ; i: 363-5.

5 Alarcon-Segovia D, Fishbein E. Immunochemical characterization of the anti RNA antibodies found in scleroderma and systemic lupus erythematosus. J Immunol 1975; 115: 28-31.

6 Douvas A, Achten A, Tan E M. Identification of a nuclear protein (Scl-70) as a unique target of human antinuclear antibodies in scleroderma. J Biol Chem 1979; 254: 10514-22.

7 Ritchie R F. Antinuclear antibodies: their frequency and diagnostic association. $N$ Engl J Med 1970; 282: 1174-8.
8 Moroi Y, Peebles C, Fritzler M, Steigerwald J, Tan E. Autoantibody to centromere (kinetochore) in scleroderma sera. Proc Natl Acad Sci USA 1980; 77: 1627-31.

9 Tan E M, Rodnan G P, Garcia I, Moroi Y, Fritzler M, Peebles C. Diversity of antinuclear antibodies in progressive systemic sclerosis. Arthritis Rheum 1980; 23: 617-25.

10 Fritzler M J, Kinsella T D, Garbutt E. The CREST syndrome; a distinct serological entity with anticentromere antibodies. $\mathrm{Am} J$ Med 1980; 69: 520-6.

11 Maddison P J, Mogavero H, Provost T, Reichlin M. The clinical significance of autoantibodies to a soluble cytoplasmic antigen in systemic lupus erythematosus and other connective tissue diseases. J Rheumatol 1979; 6: 189-95.

12 Mattioli M, Reichlin M. Characterisation of a soluble nuclear ribonucleoprotein antigen reactive with SLE sera. J Immunol 1971; 197: 1281-90.

13 Nishikai M, Reichlin M. Heterogeneity of precipitating antibodies in polymyositis and dermatomyositis. Arthritis Rheum 1980; 23: 881-8.

14 Reichlin M. Marker antibodies for the polymyositis syndromes. Rev Rhum Mal Osteoartic (XV International Congress of Rheumatology) June 1981: No. 1519 (abstract).

15 Schur P, DeAngelis D, Jackson J. Immunological detection of nucleic acids and nuclear antigens by counterimmunoelectrophoresis. Clin Exp Immunol 1974; 17: 209-18.

16 Bernstein R M, Steigerwald J C, Tan E M. Association of antinuclear and antinucleolar antibodies in progressive systemic sclerosis. Clin Exp Immunol in press.

17 Alspaugh M A, Talal N, Tan E M. Differentiation and characterisation of autoantibodies and their antigens in Sjögren's syndrome. Arthritis Rheum 1976; 19: 216.

18 Cohen A S, Reynolds W E, Franklin E C, et al. Preliminary criteria for the classification of systemic lupus erythematosus. Bull Rheum Dis 1971; 21: 643-8.

19 American Rheumatism Association criteria for the diagnosis and classification of rheumatic diseases. Primer on rheumatic diseases 1973. JAMA 1973; 224 (suppl): 138.

20 Bernstein R M, Callender M E, Neuberger J M, Hughes G R V, Williams $R$. Anticentromere antibody in primary biliary cirrhosis. Ann Rheum Dis in press.

21 Black C M, Maddison P J, Jayson M I V, et al. HLA antigens and systemic sclerosis. Arthritis Rheum in press. 